Respiration 1969;26(Suppl. 1):1-2

\title{
Contents, Vol. 26, Supplementum 1, 1969
}

2nd International Symposium on Tuberculosis, Climate, Asthma and Chronic Bronchitis

Davos (Switzerland) October 8-10, 1967 Edited by F. Suter

Index

Introduction - Einleitung 3

Schär, M. (Zurich): Umweltsfaktoren und persönliches Verhalten als Ursache von

Erkrankungen der Atmungsorgane 5

Gregg, Ian (Roehampton): Infection and Chronic Bronchitis. A Study Carried out

in General Practice 16

Chronic Pulmonary Tuberculosis - Social and Therapeutic Aspects

Chairman: Prof. G. Favez, Lausanne

Arnold, E. (Geneva): Address of the President of the Swiss Association Against

Tuberculosis 31

Birkhäuser, H. (Basle): 133 Cases of Chronic Pulmonary Tuberculosis as Sources

of Infection, Observed During a Mean Observation Time of 20 Years 33

O $\tau \tau$, A. (Solothurn): The Problem of the Chronic Pulmonary Tuberculosis in the

Epidemic View 38

Lukas, W. (Frankfurt/Main): Some Results From the Statistics of the 'Deutsche

Rentenversicherung' (German Invalide Insurance) Indicating Possible Causes of

Chronic Pulmonary Tuberculosis 39

Sighart, H. (Wien): Chronic Pulmonary Tuberculosis - Social Aspects 43

Geddes, J. E. (Glasgow): Chronic Infectious Pulmonary Tuberculosis - Social

Therapy 49

Van Geuns, H. A. (Rotterdam): Some Aspects of Chronic Pulmonary Tuberculosis 61 Virchow, Chr. (Davos): Therapeutical Aspects in Chronic Pulmonary Tuberculosis 65 Foster-Carter, A. F. (Camberley, Surrey): Chronic Tuberculosis in Refractory

Patients - Therapeutic Aspects 76

Suter, F. (Davos): The Surgical Treatment of the Chronic Pulmonary Tuberculosis 82

Discussion 89

Bronchospasmolytics

Chairman: Prof. R. Preisig, Berne

Meyer, H. (Davos): Introduction

91

Preisig, R. (Berne): The Pharmacologic Basis of Bronchospasmolytic Agents ...

McAllen, Monica (London): National Statistics on Asthma Deaths and Side

Effects of Bronchodilators 103

Ulmer, W. T. (Bochum): Bronchospasmolytics in Obstructive Airway Diseases . . 107

Rothlin, M. (Zurich): The Response of the Cardiovascular System to Sympathico-

mimetic Drugs 116

Gregg, Ian (London): Reversibility of Airways Obstruction in Asthma

Altounyan, R. E. C. and Howell, J. B. L. (Manchester): Treatment of Asthma 
with Disodium Cromoglycate (FPL 670, IntaГ)

1 Respiration Suppl. ad Vol. 26 (1969)

Special Aspects in Chronic Obstructive Lung Diseases. I. Allergy

Chairman: Dr. J. Gartmann, Arosa

Zu \&gt; ema, P. (Davos): Value of Inhalation Tests in Bronchial Asthma

Voorhorst, R. (Leiden): Further Research on House-dust Atopy in Relation to the

House-dust Mite 151

Trendelenburg, F. (Homburg, Saar): Mass-spectrometric Gas Analysis and Provo cation Tests in Asthma

163

Discussion

167

Pepys, J. (London): Pulmonary Hypersensitivity to Inhaled Organic Dusts ....

Discussion 173

Special Aspects in Chronic Obstructive Lung Diseases. II. Radiology

Chairman: Prof. R. Zuppinger, Berne

Simon, G. and Reid, L. (London): Value of X-ray for Diagnosis and Prognosis of Bronchial Obstruction Syndromes 176

Worth, G.; Muysers, K. and Smidt, U. (Moers and Bonn): Radiology and Func tional Analysis of the Lungs 190

Hers, J. F. Ph. (Leiden): Radiology of 'Bronchial' Obstruction Syndromes in Viral Infection 197

Herzog, H.; Fridrich, R.; Baumann, H. R. and Endrei, E. (Basle): The Use of Pulmonary Radioisotope Scanning and Bronchospirometry to Assess Disturb ances in Ventilation and Perfusion of the Lungs 204

Discussion 219

Chronic Bronchitis. Occupational and Social Aspects

Chairman: Dr. C. M. Fletcher, London

Higgyns, I. T. T.; Gilson, J. C.; Ferris, B. G.; Waters, W. E.; Campbell, H. M. and Higgins, M. W. (Ann Arbor, Mich.): Chronic Respiratory Disease in an Industrial Town: A Nine-year Follow-up Study 221

de Haller, R. and Suter, F. (Davos): Bronchitis in Foundry Workers223

Worth, G.; Muysers, K. and Smidt, U. (Moers and Bonn): Lung Function in Ironworkers 225

Bärtschi, R. and Regli, J. (Heiligenschwendi): Chronic Bronchitis in a Rural Area and its Prognosis 231

Beckenkamp, H. W. (Saarbrücken): Composition and Analysis of Comparative Col lectivities in Chronic Bronchitis 239

Discussion 246

Donors 247 